\title{
The utilization of solid waste treatment for charcoal making and water heating by continuous incineration
}

\author{
Erlanda Augupta Pane ${ }^{1, *}$, Hendri Sukma ${ }^{1}$, Arif Riyadi Tatak ${ }^{1}$, and Ismail ${ }^{1}$ \\ ${ }^{1}$ Department of Mechanical Engineering, Faculty of Engineering, Universitas Pancasila, Srengseng Sawah, Jakarta 12640, Indonesia
}

\begin{abstract}
The utilization of solid waste incineration still has the low percentage, whereas the incineration can add the value of solid waste. This research conducted to analyse of solid waste incineration with methods that classified into two steps that are the analyse of requirement between solid waste and air supply to determine of mass and energy balance, and the pilot scale experiment to analyse the utilization of heat energy from solid waste incineration for charcoal making and water heating. The results show that the 12.5 $\mathrm{kg}$ solid waste mass request the $5.78 \mathrm{~kg} / \mathrm{h}$ combustion rate to produce heat energy up to $134.4 \mathrm{~kJ}$, where can transform $1 \mathrm{~kg}$ coconut shell to $500 \mathrm{~g}$ charcoal and increase the water temperature from $32^{\circ} \mathrm{C}$ to $62^{\circ} \mathrm{C}$. The research will be continued with analyse of air supply for incineration process temperature increasing, which can determine the combustion rate that influences the heat energy product.
\end{abstract}

\section{Introduction}

The rate of solid waste generation which classified into two forms that is organic waste and inorganic waste (paper, plastic, glass, metal and other) [1] is an important issue that requires specific strategies treatment with the aim to reduce negative effects on the environment [2], because it can create environmental degradation with problems such as contamination of surface and groundwater through leachate, odour in landfill and uncontrolled release of methane by anaerobic decomposition of waste [3]. The solid waste has a relationship towards the country economic growth that has meant the high populations with the high living standards can increase the solid waste product continuously [4], which that condition can be viewed by the low and middle-income country (that is Indonesia, Malaysia, Thailand and Vietnam) [5]. The relationship between the people population and solid waste generation can be shown in Table 1.

Table 1. Waste generation by region ${ }^{6}$

\begin{tabular}{|c|c|c|c|}
\hline \multirow[b]{2}{*}{ Region } & \multirow{2}{*}{$\begin{array}{c}\text { Total urban } \\
\text { population } \\
\text { (milions) }\end{array}$} & \multicolumn{2}{|c|}{ Urban waste generation } \\
\hline & & $\begin{array}{c}\text { Per capita } \\
\text { (kg/capita/day) }\end{array}$ & $\begin{array}{c}\text { Total } \\
\text { (tons/day) }\end{array}$ \\
\hline $\begin{array}{c}\text { High } \\
\text { income }\end{array}$ & 774 & 2.13 & 1.649 .547 \\
\hline $\begin{array}{l}\text { Upper } \\
\text { middle } \\
\text { income }\end{array}$ & 572 & 1.16 & 665.586 \\
\hline $\begin{array}{l}\text { Lower } \\
\text { middle } \\
\text { income }\end{array}$ & 1293 & 0.78 & 1.012 .321 \\
\hline $\begin{array}{l}\text { Lower } \\
\text { income }\end{array}$ & 343 & 0.60 & 204.802 \\
\hline Total & 2982 & 1.19 & 3.532 .256 \\
\hline
\end{tabular}

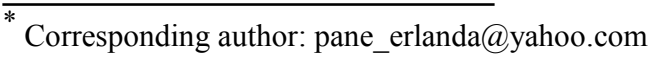

Source: ${ }^{6}$ Daniel H, Perinaz, B.T, 2012

Generally, the solid waste product in the country with low-and middle-income has the organic waste percentage of $59 \%$ and inorganic waste percentage that classified into $9 \%$ paper, $12 \%$ plastic, $3 \%$ glass, $2 \%$ metals and $15 \%$ other [6].

The reducing of solid waste with the treatment in the low-and middle-income country still has the problem with the operational system, which they have the poorly operated landfill to solve the solid waste issue [6]. The low-and middle-income country, especially in Indonesia, has the solid waste treatment that dominated with the solid waste dumping in the landfill. The landfill area for solid waste dumping can reach up to 500 landfills [7] for the percentage of solid waste dumping of $69 \%$ [8]. In the other hand, the number of solid waste through the open dumping without pre-heated treatment is 2.2 million tons, and the number of solid waste through the open burning in the landfill is 0.05 million tons [5], where that treatment still has the negative effect to an environment that has described previously. The reducing of negative effect from that solid waste treatment can be solved by the one of treatment i.e. incineration process. Incineration is a solid waste treatment with the combustion activity in the closed chamber, where its activity can generate the heat and energy that can be utilized for the other aims [9]. The incineration process needs the control system of temperature with the temperature range from $500^{\circ} \mathrm{C}$ until $1100^{\circ} \mathrm{C}$ that depended upon the type and volume of solid waste, where it can occur for reducing the negative effect that due to the air pollution from the solid waste combustion in the closed chamber $[9,10]$. However, Indonesia with the incineration process still has a low percentage with the value of $2 \%$ [8], meanwhile the incinerator has the 
some advantages to improve the solid waste utilization such as the incineration can reduce the volume and mass of solid waste up to $90 \%$ and $75 \%$ respectively, eliminating pathogens and add the value of solid waste utilize to generate heat which can be transformed to electricity or used for water heating [11]. Incineration process can be classified into two forms that is the batch incineration and continuous incineration. The difference between batch type and continuous type of incineration positioned in the feed rate of solid waste to the combustion chamber, where the batch type has the low rate value than the continuous type [12], where it can influence the combustion rate for produce the heat energy of solid waste in the combustion chamber.

This research was conducted to analyse heat energy utilization from solid waste incineration to generate the charcoal from coconut shell and water heating. The request of incinerator operational temperature to compose of charcoal is the temperature between $300^{\circ} \mathrm{C}$ until $900^{\circ} \mathrm{C}$ [13]. On the other hand, the water heating temperature can increase from $30^{\circ} \mathrm{C}$ (ambient temperature) to $100^{\circ} \mathrm{C}$. The previous research of batch type incineration by Pradipta [14] can be shown in figure 1.

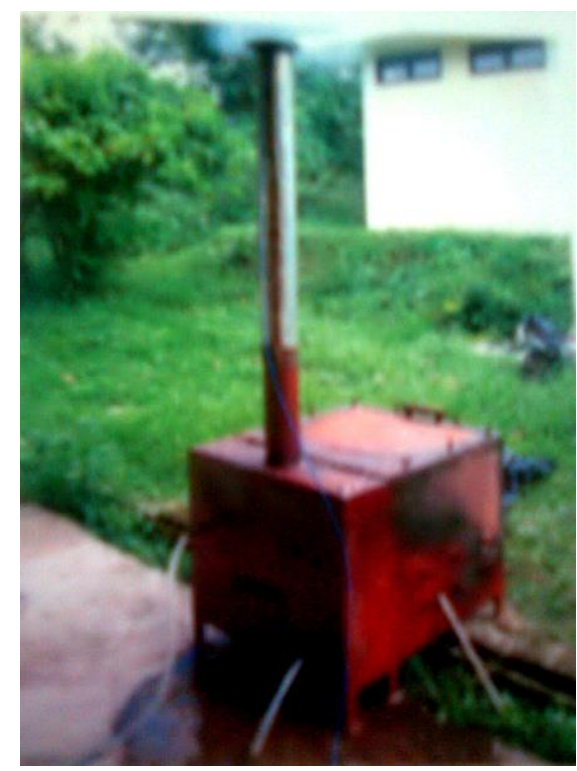

Fig. 1. Batch type incineration [14]

The results of batch type incineration can be shown in Table 2, where the utilization of heat energy for charcoal making and water heating not optimum yet, caused by the decrease of incineration temperature when the change of solid waste feeding rate to combustion chamber that triggers of heat energy losses.

Table 2. The previous result of research ${ }^{14}$

\begin{tabular}{|c|l|c|}
\hline No. & \multicolumn{1}{|c|}{ Parameter } & Quantity \\
\hline 1. & Solid waste mass & $10.5 \mathrm{~kg}$ \\
\hline 2. & Air velocity & $1.105 \mathrm{~m} / \mathrm{s}$ \\
\hline 3. & Combustion rate & $6.82 \mathrm{~kg} / \mathrm{h}$ \\
\hline 4. & Heat energy & $16.26 \mathrm{~kJ}$ \\
\hline 5. & Total of charcoal & $0.5 \mathrm{~kg}$ \\
\hline 6. & Water temperature & $47^{\circ} \mathrm{C}$ \\
\hline
\end{tabular}

This research has the aims to increase the utilization of heat energy, which have the rise of heat value from the solid waste incineration with the change of incineration type from batch type to continuous type. The parameters that influence of heat energy that is combustion temperature, air velocity, combustion rate, waste solid moisture content and mass of solid waste.

\section{Materials and Tools}

Materials that used is a solid waste with the moisture content between $12.4 \%$ until $15.3 \%$ w.b, the coconut shell with the total mass of $1 \mathrm{~kg}$ and water with the flow rate is $0.08 \mathrm{lt} / \mathrm{s}$. The tools that used is thermometer gauge (KW06-565) type K, thermocouple cable type TC-10K, Recorder Type Yokogawa 3056, Anemometer type DT82, Digital Moisture Tester Type AG-07, Alcohol Thermometer, Incinerator with the capacity of 10-12.5 $\mathrm{kg}$ and Digital Scales type Camry with the maximum scale of weight measurement is $5 \mathrm{~kg}$, and minimum scale of measurement is $0.001 \mathrm{~kg}$.

\section{Method}

The principle working of incineration process based on the mass balance between solid waste and air [15]. The mass balance equation 1 .

$$
\mathrm{C}_{a} \mathrm{H}_{b} \mathrm{O}_{c} \mathrm{~N}_{d}+\left(a+\frac{b}{4}-\frac{c-d}{2}\right) \mathrm{O}_{2} \rightarrow a \mathrm{CO}_{2}+\frac{b}{2} \mathrm{H}_{2} \mathrm{O}+d \mathrm{NO}
$$

Pitchel [13] said that the request of oxygen mass to incinerate influenced by hydrogen and carbon amount, where the carbon weight of $1 \mathrm{~kg}$ need $1.96 \mathrm{~m}^{3}$ oxygen, and $1 \mathrm{~kg}$ hydrogen need $5.85 \mathrm{~m}^{3}$ oxygen [15]. The request for minimum oxygen mass $\left(\mathrm{W}_{\mathrm{min}}\right)$ to incinerate can be calculated by the equation 2 .

$$
W_{\min }=\left(\frac{100}{21}\right) *[(1.96 * C)+(5.85 * H)]
$$

Where, $\mathrm{C}$ is carbon content and $\mathrm{H}$ is hydrogen content. The combustion rate $(\mathrm{Bbt})$ can be explained by the divide equation between solid waste mass (m) and incineration time (t) [15], which can be shown in equation 3.

$$
B b t=\frac{m}{t}
$$

Based on the equation (2) and (3), the request of oxygen minimum rate $(\mathrm{Q})$ can be decided with the excess of air up to $40 \%$. The request of oxygen minimum rate can be shown in equation 4 .

$$
\begin{aligned}
& Q_{\text {air }}=W_{\min } * B b t \\
& Q=Q_{\text {air }} *(1+40 \%)
\end{aligned}
$$

Where, $\mathrm{Q}_{\text {air }}$ is an air flow rate. The heat transfer in the incinerator through two methods that is conduction and convection process. The conduction and convection process can aid the charcoal making process and water 
heating. Lienhard [16] said that the heat transfer of conduction process (q) can be calculated by equation 5 .

$$
q=k A \frac{d T}{d r}
$$

Where, $\mathrm{k}$ is a thermal conduction coefficient material, $\mathrm{A}$ is a surface area, and the value of $\frac{d 7}{d r}$ is a value that influenced by a material form of water pipe, where the water heating process use the pipe with the cylinder form [16]. The value of $\frac{d 7}{d r}$ can be calculated by equation 6 .

$$
\frac{d T}{d r}=\frac{1}{\ln \left(\frac{r_{i}}{r_{o}}\right)} *\left(T_{i}-T_{o}\right)
$$

Where, $r_{o}$ is an outside diameter of water pipe, $r_{i}$ is an inside diameter of water pipe, $T_{i}$ is an inside pipe temperature and $T_{0}$ is an outside pipe temperature. The heat transfer with the convection process in the incineration influenced by the airflow type, which can be known by Reynolds number (Re) and Nusselt number $\left(\mathrm{Nu}_{\mathrm{d}}\right)$. The convection method [16] can be shown in the equation 7 .

$$
\begin{gathered}
\operatorname{Re}=\frac{V d}{v} \\
N u_{d}=0.023 * \operatorname{Re}^{0.8} * \operatorname{Pr}^{n} \\
h=k \frac{N u_{d}}{r} \\
q=h * A *\left(T_{s}-T_{\infty}\right)
\end{gathered}
$$

Where, $\mathrm{h}$ is convection coefficient materials, $\mathrm{Pr}$ is a Prandtl numbers, $\mathrm{D}$ is a pipe diameter, $\mathrm{T}_{\mathrm{s}}$ is a wall temperature, $\mathrm{T} \infty$ is an ambient temperature and $\mathrm{q}$ is a heat transfer of convection process.

The experiment pilot scale of solid waste incineration takes the inorganic solid waste because the inorganic solid waste has the difficult of biological decomposition [17]. The percentage of inorganic solid waste for the experiment can be classified into the $42 \%-96 \%$ paper, $50 \%-55 \%$ plastics, and $41 \%$ dry leaf. The results of the experiment that be known are incineration time, combustion rate, heat energy, the total of charcoal, air velocity, exhaust gas characteristics and temperature in the incinerator system

The mechanism of incineration process can be explained based on Figure 2, where the loading of solid waste from the hopper (1), would be the entrance to the combustion chamber (2). In the combustion chamber, the solid waste incinerated by the high temperature which can produce exhaust gas and heat energy. The water heater pipe (5) his position in the inner incinerator side can be received heat energy by convection and conduction method through the wall that becomes the boundary plate (4). The loading of coconut shell in the charcoal chamber (6) can also be received the heat energy from the combustion chamber by convection and conduction method and the addition of coconut shell can also aid to filter the exhaust gas that has the hazardous particles. Therefore, the coconut shell can be transformed to charcoal caused by the heat energy from the exhaust gas and the exhaust gas that leave the incinerator to the environment through the chimney (7) can be delivered without the hazardous particle. The ash as a by-product of solid waste incineration can be distributed to ash chamber in the bottom of the combustion chamber (3).

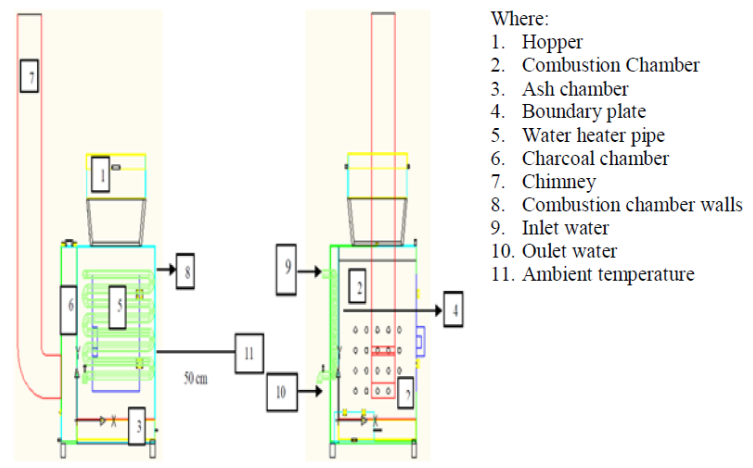

Fig. 2. The mechanism of continuous incinerator

\section{Result and Discussion}

The solid waste treatment by the continuous type is an incineration process type with the high feed rate to combustion chamber than the batch type. The incineration process can be shown in Figure 3.

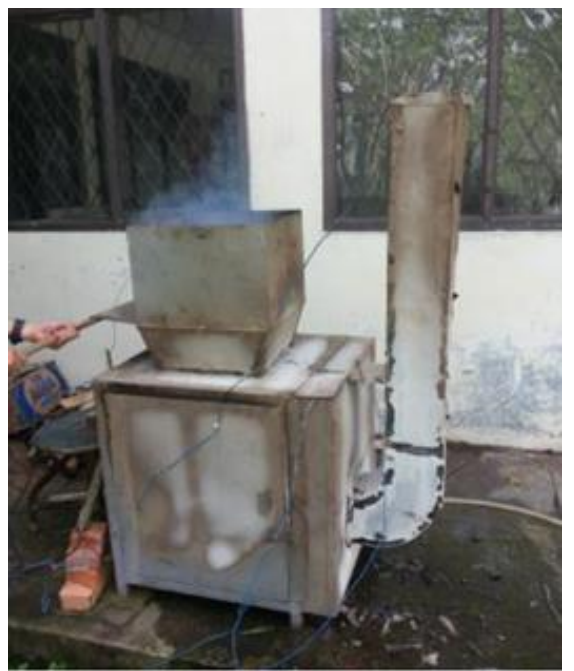

Fig. 3. Continuous type incineration

The results of research shown in Table 3, where the incineration process can produce the heat energy is 134 $\mathrm{kJ}$ based on the combustion rate of $5.78 \mathrm{~kg} / \mathrm{h}$. The results can be reached by the solid waste incinerate temperature of $698.6^{\circ} \mathrm{C}$ and air supply with the velocity of $1.882 \mathrm{~m} / \mathrm{s}$, where it can be concluded that the comparison of the continuous type incinerator towards the previous type has occurred the improvement of performance. These condition can be shown that the rise of heat energy product for water heating influenced by the increase of air velocity that entrance into the incinerator, where the 
results of water heating can be known by rises the outlet water temperature that can reach up to $62^{\circ} \mathrm{C}$ rather than the temperature of outlet water in the previous incinerator type that only can reach up to $47^{\circ} \mathrm{C}$.

Table 3. Results of experiment solid waste incineration

\begin{tabular}{|c|l|c|}
\hline No. & \multicolumn{1}{|c|}{ Parameter } & Quantity \\
\hline 1. & Solid waste mass $(\mathrm{kg})$ & $10-12.5$ \\
\hline 2. & Moisture content $(\%)$ & $12.4-15.3$ \\
\hline 3. & Incineration time (hours) & $2.16-3.16$ \\
\hline 4. & Combustion rate $(\mathrm{kg} / \mathrm{h})$ & $3.16-5.78$ \\
\hline 5. & Heat energy $(\mathrm{kJ})$ & $42-134$ \\
\hline 6. & Total of charcoal $(\mathrm{kg})$ & $0.2-0.5$ \\
\hline 7. & Air velocity $(\mathrm{m} / \mathrm{s})$ & 1.822 \\
\hline 8. & Exhaust gas colour & Transparent \\
\hline 9. & Exhaust gas odour & - \\
\hline 10. & Incineration temperature $\left({ }^{0} \mathrm{C}\right)$ & \\
& a. Combustion chamber side & $294.6-453.7$ \\
& b. Combustion chamber centre & $322.5-689.6$ \\
& c. Wall & $136.8-284.5$ \\
& d. Chimney & $133.5-326.1$ \\
& e. Water pipe & $65-155.5$ \\
& f. Water inlet & $28-32$ \\
& g. Water outlet & $40-62$ \\
& h. Ash chamber & $152.7-432.4$ \\
\hline
\end{tabular}

The utilization of heat energy also can aid to optimal coconut shell transform into charcoal, where the $1 \mathrm{~kg}$ of coconut shell can produce $0.5 \mathrm{~kg}$ charcoal. The result of charcoal can be shown in Figure 4.
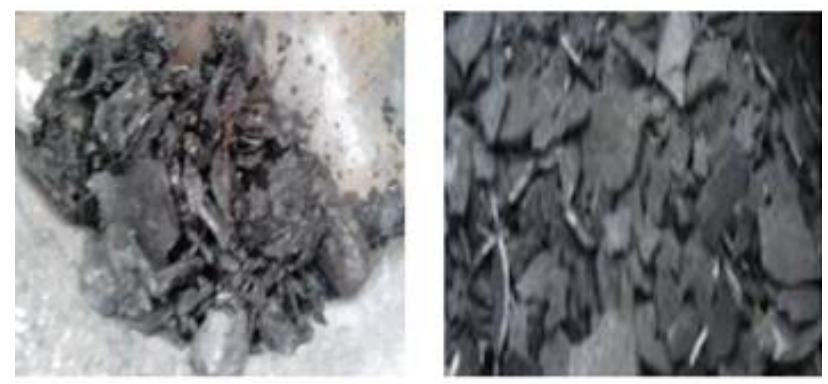

Fig. 4. Charcoal

The increase of water temperature in the water heater pipe that previously described caused by the conduction process between boundary plate toward water pipe and convection process between the air flow in the combustion chamber and boundary plate that distribute the heat energy. The water heater pipe that has the spiral form also can add the heat energy distribution to heat the water flow in the inner of pipe, where it can be known by the mechanism of heat energy received for water flow in every level of pipe has the increase of temperature. The conduction and convection process can be shown in figure 5 .

The exhaust gas from solid waste incineration that can be shown in Figure 6 (a) is not contained the hazard particle, where this condition that shown in figure 6 (b) caused by the charcoal that being as a filter for exhaust gas, moreover the chimney shape that gives the centrifugal effect which can make the hazard particle as a light particle was separated towards the exhaust gas and dropped to the charcoal chamber. The decrease of combustion rate caused by the high of solid waste moisture content that can obstruct the heat distribution to combustion reaction and moreover the mostly of air hole position was applied in the center area also influence these condition.

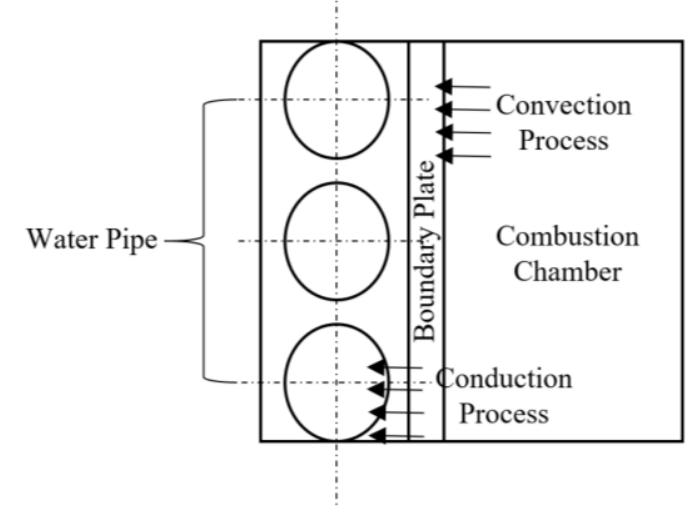

Fig. 5. Conduction and convection process

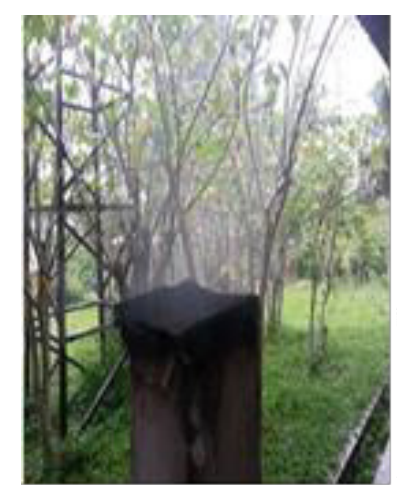

(a)

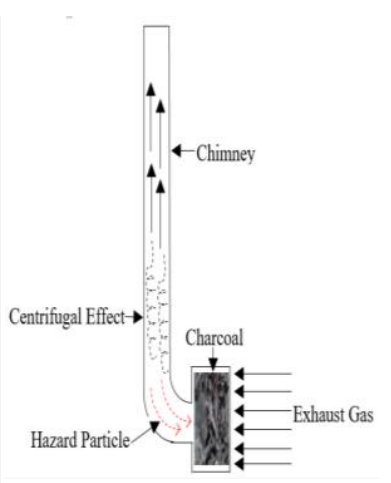

(b)
Fig.6. Exhaust gas condition (a) and mechanism (b)

The condition can give the combustion reaction only been occurs in the centre area with the high temperature, meanwhile on the other side has the lowest temperature and it can trigger of the incineration time to have a long time for reducing of solid waste.

\section{Conclusion}

The results of research can be concluded that the solid waste through continuous incineration process is able to produce heat energy with the value of $134 \mathrm{~kJ}$, which utilized for charcoal making with the mass result of 0.5 $\mathrm{kg}$ and the rises of water temperature from $320 \mathrm{C}$ to 620C. The research will be continued with air supply analyse caused by the distribution of temperature in the combustion chamber not optimum yet. The air supply can determine the combustion rate that influences the heat energy produced.

The authors are grateful to the laboratories product of mechanical engineering Universitas Pancasila.

\section{References}

1. S. Ghanimeh, M. El Fadel, P. Saikaly, Bioresource technology mixing effect on thermophilic anaerobic 
digestion of source-sorted organic fraction of municipal solid waste. Bioresource Technology. 117, 63-71 (2012)

2. Q. Song, J. Li, X. Zeng, Minimizing the increasing solid waste through zero waste strategy. Journal of Cleaner Production. 104, 199-210 (2015)

3. U. Nguyen Ngoc, H. Schnitzer, Sustainable solutions for solid waste management in Southeast Asian Countries. Waste Management. 29, 1982-1995 (2009)

4. X. Lu, X. Zhai, M. Huang, Characterization of the constitutive behaviour of municipal solid waste considering particle compressibility. Waste Management. 69, 3-12 (2017).

5. S. Norkhadijah Syed Ismail, L. Abd. Manaf, The challenge of future landfill: A case study of Malaysia. Toxicology and Environmental Health Science. 5, 86-96 (2013)

6. Daniel H, Perinaz B.T, A global review of solid waste management 15th ed (World Bank Report, Washington, 2012)

7. Kristanto G A, Gusniani I, Ratna A, The performance of municipal solid waste recycling program in Depok, Indonesia. International Journal of Technology. 2, 264-272 (2015)

8. C. Ryu, Potential of municipal solid waste for renewable energy production and reduction of greenhouse gas emissions in South Korea. Journal of the Air \& Waste Management Association. 2247, 176-183 (2010)

9. Yuliansyah A T, Prasetya A, Ramadhan M A A, Laksono R, Pyrolysis of plastic waste to produce pyrolytic oil as an alternative fuel. International Journal of Technology. 7, 1076-1083 (2015)

10. D. Mudgal, L. Ahuja, D. Bhatia, S. Singh, S. Prakash, High temperature corrosion behaviour of super alloys under actual waste incinerator environment. Engineering Failure Analysis. 63, 160171 (2016)

11. F.A.M. Lino, K.A.R. Ismail, Incineration and recycling for MSW treatment: Case study of Campinas, Brazil. Sustainable Cities and Society. 35, 752-757 (2017)

12. J.R. Hart, Transient puffs of trace organic emissions from a batch-fed waste propellant incinerator. Chemosphere. 42, 559-569 (2001)

13. L. Wang, E. Barta-Rajnai, K. Hu, C. Higashi, O. Skreiberg, M. Gronli, Z. Czegeny, E. Jakab, V. Myrvagnes, G. Varhegyi, M.J. Antal Jr, Biomass charcoal properties changes during storage. Energy Procedia. 105, 830-835 (2017)

14. Pradipta A.N.G, Design and performance test of incinerator batch type for urban areas with the addition of water heater (Institut Pertanian Bogor, 2011)

15. Pitchel J, Waste management municipal, hazardous and industrial (CRC Press, New York, 2005)

16. Lienhard J, A heat transfer textbook $3^{\text {rd }}$ ed (Phlogiston Press, Massachusetts, 2002)

17. A.A. Zabaniotou, G. Stavropoulos, Pyrolysis of used automobile tires and residual char utilization. Journal of Analytical and Applied Pyrolysis. 70, 711-722 (2003) 